\title{
Molten Salt Synthesis of Different Ionic Radii Metallic Compounds Doped Lithium Titanate Used in Li-Ion Battery Anodes
}

\author{
Qingjun Guo ${ }^{1}$, Qiang Wang ${ }^{1}$, Gang Chen ${ }^{1}$, Miao Shen ${ }^{2}$ and Bing Li $^{1}{ }^{* *}$ \\ ${ }^{1}$ East China University of Science and Technology, 130Meilong Road, Shanghai 200237, P.R. China \\ ${ }^{2}$ Shanghai Institute of Applied Physics, Chinese Academy of Sciences, Shanghai 201800, P.R. China
}

\begin{abstract}
In order to systematically characterize the effects of ion doping on $\mathrm{Li}_{4} \mathrm{Ti}_{5} \mathrm{O}_{12}$ (LTO) through the molten salt method, different metallic compounds with varying ionic radii doped into LTO were investigated. The results show that doped ions $\left(\mathrm{Al}^{3+}, \mathrm{Ni}^{2+}, \mathrm{Fe}^{2+}, \mathrm{Fe}^{3+}\right.$ and $\left.\mathrm{F}^{-}\right)$with similar ionic radius as $\mathrm{Li}^{+}, \mathrm{Ti}^{4+}$ or $\mathrm{O}^{2-}$ ions can enter into LTO, which leads to smaller particle size than pure LTO, therefore, increasing the specific surface area and shortening $\mathrm{Li}^{+}$transfer path of LTO. However, $\mathrm{La}^{3+}$ with a much larger ionic radius cannot enter into LTO. Ion doping can enhance the intrinsic conductivity of LTO, thus improving the electrochemical performance of LTO. As the ionic radii of Fe $\mathrm{F}^{2+}$ and Fe $\mathrm{F}^{3+}$ are the closest to those of $\mathrm{Li}^{+}$and $\mathrm{Ti}^{4+}, \mathrm{Fe}_{3} \mathrm{O}_{4}$ doped $\mathrm{LTO}$ exhibits the best electrochemical performance, an excellent first discharge capacity of $269.3 \mathrm{mAh} \cdot \mathrm{g}^{-1}$ at the $0.15 \mathrm{C}$, good high-rate capability $\left(123.4 \mathrm{mAh} \cdot \mathrm{g}^{-1}\right.$ at $\left.10 \mathrm{C}\right)$; even after 300 discharge/charge cycles, the discharge capacity is $141.1 \mathrm{mAh} \cdot \mathrm{g}^{-1}$, gives an excellent cycle performance with $12.4 \%$ loss of capacity at $1 \mathrm{C}$ rate. Due to these factors, $\mathrm{Fe}_{3} \mathrm{O}_{4}$ is the most suitable metallic compound doped in LTO via molten salt method. [doi:10.2320/matertrans.MK201607]
\end{abstract}

(Received August 30, 2016; Accepted December 5, 2016; Published February 25, 2017)

Keywords: molten salt, metallic compound, lithium titanate, lithium-ion battery

\section{Introduction}

Spinel-type lithium titanate $\left(\mathrm{Li}_{4} \mathrm{Ti}_{5} \mathrm{O}_{12}\right.$, LTO) with zero

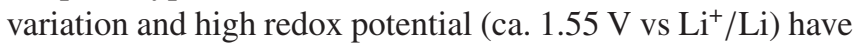
garnered extensive attention owning to excellent reversibility in lithium insertion/extraction reactions and high safety ${ }^{1,2)}$. Its intrinsic advantages also include fast electrode kinetics enhanced and its high thermodynamic stability ${ }^{3)}$. However, the low intrinsic electrical conductivity $\left(\sim 10^{-13} \mathrm{~S} \mathrm{~cm}^{-1}\right)$ and the inherently sluggish lithium-ion diffusion coefficient of bulk LTO greatly limit its rate capability, as well as its practical implementation ${ }^{4-9)}$.

The improvement for the rate performance of $\mathrm{Li}_{4} \mathrm{Ti}_{5} \mathrm{O}_{12}$ anode have been widely studied over the past decade, which can be roughly divided into two strategies. One strategy is to improve electron transfer by ion doping, surface modification, and/or incorporation of carbon ${ }^{10-26)}$. The other approach is to reduce the electron and $\mathrm{Li}$-ion diffusion lengths by producing nanostructured analogues of $\mathrm{Li}_{4} \mathrm{Ti}_{5} \mathrm{O}_{12}$ itself ${ }^{27-31}$ ). Among these methods, ions doping can efficiently improve the intrinsic conductivity of LTO, smaller particle size can shorten the Li-ion transfer route, thereby improving the rate performance.

Commercially, LTO is synthesized by a conventional solid-state method. The process is usually assisted by long-time ball-milling and high-temperature sintering. The synthesized LTO materials are composed of bulk particles, inhomogeneous and hard to be removed from the reaction vessel. The molten salt synthesis method has shown more advantages in controlling composition, morphology, homogeneity and high crystallinity ${ }^{11)}$. In addition, the molten salt method is one of the most effective paths to one-step synthesis of multiple compounds, so it will be easier to introduce hetero-elements through molten salt method. For instance, $\mathrm{Mn}^{4+}$ doped $\mathrm{Li}_{4} \mathrm{Ti}_{5} \mathrm{O}_{12}$ was synthesized by molten salt method via calcination of the mixture of $\mathrm{MnO}_{2}, \mathrm{LiOH} \cdot \mathrm{H}_{2} \mathrm{O}, \mathrm{TiO}_{2}$ and $\mathrm{LiCl}-\mathrm{KCl}$ at $800^{\circ} \mathrm{C}$ for $10 \mathrm{~h}$, has shown a relatively lower particle size

*Corresponding author, E-mail: bingli@ecust.edu.cn, drlibing@163.com (around $1.125 \mu \mathrm{m}$ ) than the pure $\mathrm{Li}_{4} \mathrm{Ti}_{5} \mathrm{O}_{12}$, giving better first discharge capacity ( $305 \mathrm{~mA} \mathrm{~h} \mathrm{~g}^{-1}$ ) between $0-3 \mathrm{~V}$ and a corresponding to coulombic efficiency of $89 \%$ at $0.1 \mathrm{C}$ rate ${ }^{13)}$. In our previous work, $\mathrm{Fe}_{2} \mathrm{O}_{3}$ and $\mathrm{Co}_{3} \mathrm{O}_{4}$ were used to optimize modified LTO through the molten salt method to improve LTO's electrical conductivity. Also the modification exhibited other good effects: the obtained $\mathrm{Li}_{4} \mathrm{Ti}_{4.8} \mathrm{Fe}_{0.2} \mathrm{O}_{12}$ gave a capacity of $103.4 \mathrm{~mA} \mathrm{~h} \mathrm{~g}^{-1}$ at $10 \mathrm{C}, 137.4 \mathrm{~mA} \mathrm{~h} \mathrm{~g}^{-1}$ at the $0.2 \mathrm{C}$ rate after 50 cycles ${ }^{11}$. The $\mathrm{Li}_{4} \mathrm{Ti}_{4.9} \mathrm{Co}_{0.1} \mathrm{O}_{12}$ exhibited a better high-rate capacity $106 \mathrm{mAh} \cdot \mathrm{g}^{-1}$ at $10 \mathrm{C}$, and $144.8 \mathrm{mAh} \cdot \mathrm{g}^{-1}$ at $1 \mathrm{C}$ rate with the capacity loss of $8.8 \%$ after 100 charge/ discharge cycles ${ }^{12)}$.

In order to systematically characterize the effects of ion doping on the particle size, conductivity and electrochemical performances of LTO as Li-ion battery anodes via the molten salt method, the different metallic compounds $\left(\mathrm{Al}_{2} \mathrm{O}_{3}, \mathrm{NiO}\right.$, $\mathrm{Fe}_{3} \mathrm{O}_{4}, \mathrm{La}_{2} \mathrm{O}_{3}, \mathrm{LaF}_{3}, \mathrm{CeF}_{3}$ ) with varying ionic radii doped in $\mathrm{Li}_{4} \mathrm{Ti}_{5} \mathrm{O}_{12}$ were investigated. The results show that doped cations $\left(\mathrm{Al}^{3+}, \mathrm{Ni}^{2+}, \mathrm{Fe}^{2+}, \mathrm{Fe}^{3+}\right)$ or anion $\left(\mathrm{F}^{-}\right)$with similar ionic radii to $\mathrm{Li}^{+}, \mathrm{Ti}^{4+}$ or $\mathrm{O}^{2-}$ ions can enter into $\mathrm{LTO}$, which leads to smaller particle size compared to pure LTO. However, $\mathrm{La}^{3+}$ with a larger ionic radius cannot enter into LTO. Because the ionic radii of $\mathrm{Fe}^{2+}$ and $\mathrm{Fe}^{3+}$ are the closest to that of $\mathrm{Li}^{+}$and $\mathrm{Ti}^{4+}$ and variable valency ions co-doping, $\mathrm{Fe}_{3} \mathrm{O}_{4}$ doped LTO exhibits the best rate and cycle performance: an excellent first discharge capacity of $269.3 \mathrm{~mA} \mathrm{~h} \mathrm{~g}^{-1}$ at the $0.15 \mathrm{C}$; excellent high-rate capability (123.4 $\mathrm{mA} \mathrm{h} \mathrm{g}^{-1}$ at $10 \mathrm{C}$ ); even after 300 discharge/charge cycles, it gives an excellent cycle performance with $12.4 \%$ loss of capacity at $1 \mathrm{C}$ rate. It seems $\mathrm{Fe}_{3} \mathrm{O}_{4}$ is the most suitable metallic compound doped in LTO via molten salt method.

\section{Experimental Procedure}

\subsection{Materials synthesis}

Anatase $\mathrm{TiO}_{2}$ (100 $\mathrm{nm}$ in average particle diameter, 99.5\% AR, XiyaReagent, Ltd.), $\mathrm{LiOH} \cdot \mathrm{H}_{2} \mathrm{O}(99.9 \% \mathrm{RG}$, Adamas Reagent, Ltd.), $\mathrm{LiCl}, \mathrm{KCl}, \mathrm{Al}_{2} \mathrm{O}_{3}, \mathrm{NiO}, \mathrm{Fe}_{3} \mathrm{O}_{4}(99.0 \%$ AR, Sino- 
pharm Chemical Reagent Co., $\mathrm{Ltd}$.), $\mathrm{La}_{2} \mathrm{O}_{3}, \mathrm{LaF}_{3}, \mathrm{CeF}_{3}$ were used as raw materials.

Pure LTO, as well as $\mathrm{Al}_{2} \mathrm{O}_{3}, \mathrm{NiO}, \mathrm{Fe}_{3} \mathrm{O}_{4}, \mathrm{La}_{2} \mathrm{O}_{3}, \mathrm{LaF}_{3}$, $\mathrm{CeF}_{3}$ doped $\mathrm{LTO}$ were prepared by $\mathrm{LiOH} \cdot \mathrm{H}_{2} \mathrm{O}(0.85 \mathrm{~g}), \mathrm{TiO}_{2}$ $(2 \mathrm{~g}), \mathrm{LiCl}(10.2 \mathrm{~g}), \mathrm{KCl}(12.46 \mathrm{~g})$ without or with $\mathrm{Al}_{2} \mathrm{O}_{3}$ (0.106 g), $\mathrm{NiO}(0.078 \mathrm{~g}), \mathrm{Fe}_{3} \mathrm{O}_{4}(0.04 \mathrm{~g}), \mathrm{La}_{2} \mathrm{O}_{3}(0.194 \mathrm{~g}$ or $0.388 \mathrm{~g}), \mathrm{LaF}_{3}(0.049 \mathrm{~g}, 0.098 \mathrm{~g}, 0.147 \mathrm{~g}$ or $0.196 \mathrm{~g})$ or $\mathrm{CeF}_{3}$ $(0.05 \mathrm{~g}$ or $0.1 \mathrm{~g})$, after the same treatment processes as described in our previous work ${ }^{11}$. The obtained products were labeled as pure LTO, LTAO, LTNO, LTFO, $\mathrm{LTLa}_{\mathrm{x}} \mathrm{O}(\mathrm{x}=0.1$, $0.2), \mathrm{LTLa}_{\mathrm{x}} \mathrm{OF}_{3 \mathrm{x}}(\mathrm{x}=0.05,0.1,0.15,0.2), \mathrm{LTCe}_{\mathrm{x}} \mathrm{OF}_{3 \mathrm{x}}(\mathrm{x}=$ $0.05,0.1,0.15)$, respectively.

\subsection{Characterization}

$\mathrm{X}$-ray diffraction (XRD) patterns of the products were recorded on a D/max $2550 \mathrm{~V}$ using $\mathrm{Cu} \mathrm{K} \alpha$ radiation. Scanning electron microscopy (SEM) images were obtained on a S-3400N scanning electron microscope.

Electrochemical characterization of the products was carried out in half cells (CR2016 coin cells), using Li metal $(\Phi 16 \mathrm{~mm} \times 1.5 \mathrm{~mm}$, China Energy Lithium Co., Ltd. $)$ as the counter electrode, PP-PE-PP three layer composite separators (25 $\mu \mathrm{m}$, UBE, Japan) saturated with $1 \mathrm{M} \mathrm{LiPF}_{6}$ in EC, DMC and EMC (1:1:1 in volume) as the electrolyte (Shenzhen Capchem Polytron Technologies Inc, China). The working electrode consisted of 80 mass $\%$ active products, 10 mass $\%$ polyvinylidene fluoride (PVDF) as a binder, 10 mass\% carbon black (Super-P) as conductive additive, and copper foil as current collector. Typically, about $1.5 \mathrm{mg}$ of the active materials was used per cell. Discharge/charge tests were conducted at room temperature using a New Ware CT-3008 battery tester at various rates $\mathrm{C}$ between 2.5 and $1.0 \mathrm{~V}(1 \mathrm{C}=$ $\left.175 \mathrm{mAh} \cdot \mathrm{g}^{-1}\right)$.

\section{Results and Discussion}

\subsection{Effect on structure and morphology by $\mathrm{Al}_{2} \mathrm{O}_{3}, \mathrm{NiO}$ and $\mathrm{Fe}_{3} \mathrm{O}_{4}$ doping}

Figure 1(a) gives the XRD patterns of the pure LTO, LTAO, LTNO, LTFO samples. All the samples are in good agreement with the standard pattern of spinel $\mathrm{Li}_{4} \mathrm{Ti}_{5} \mathrm{O}_{12}$, with all the diffraction peaks indexed to the cubic spinel structure from the Fd3m space group (JCPDS No. 49-0207, the blue peaks at the bottom). Neither the new lithium titanium oxide phase nor doped compound $\left(\mathrm{Al}_{2} \mathrm{O}_{3}, \mathrm{NiO}\right.$ or $\left.\mathrm{Fe}_{3} \mathrm{O}_{4}\right)$ was detected, which indicates that there is no structural change in $\mathrm{Li}_{4} \mathrm{Ti}_{5} \mathrm{O}_{12}$. However, from the enlarged XRD patterns of Fig. 1(b), the peaks of the LTAO, LTNO, LTFO shift to higher diffraction angles to various degrees, indicating the lattice parameters decrease. It can be concluded that the $\mathrm{Al}^{3+}, \mathrm{Ni}^{2+}, \mathrm{Fe}^{2+}$ and $\mathrm{Fe}^{3+}$ ions enter the crystal lattice. The decreased lattice parameter of LTAO may be explained that the ionic radius of $\mathrm{Al}^{3+}$ ion $(0.050 \mathrm{~nm}$, in Table 1, the same below) is smaller than that of $\mathrm{Li}^{+}$ion $(0.060 \mathrm{~nm})$ and $\mathrm{Ti}^{4+}$ ion $(0.068 \mathrm{~nm})$, so that they can enter into the crystal lattice and substitute $\mathrm{Li}^{+}$or $\mathrm{Ti}^{4+}$ ion. As for LTFO samples, the ionic radius of $\mathrm{Ti}^{4+}$ ion is between that of $\mathrm{Fe}^{2+}$ ion $(0.076 \mathrm{~nm})$ and $\mathrm{Fe}^{3+}$ ion $(0.064 \mathrm{~nm})$, and the ionic radii of the three ions and $\mathrm{Li}^{+}$ion are extremely close, so $\mathrm{Li}^{+}$ and $\mathrm{Ti}^{4+}$ ions are easily substituted by $\mathrm{Fe}^{2+}$ or $\mathrm{Fe}^{3+11,32)}$. However, the radius of $\mathrm{Ni}^{2+}$ ion $(0.072 \mathrm{~nm})$ is a little larger than that of $\mathrm{Li}^{+}$ion and $\mathrm{Ti}^{4+}$ ion, so the influence of $\mathrm{Ni}^{2+}$ is not so obvious. Ion doping can improve the intrinsic conductivity of LTO as the substitution atoms could cause vacant sites of LTO. The co-doping of variable valence $\mathrm{Fe}^{2+}$ and $\mathrm{Fe}^{3+}$ ions has relatively large effect on the redox reaction as the twophase reaction of $\mathrm{Li}_{7} \mathrm{Ti}_{5} \mathrm{O}_{12} / \mathrm{Li}_{4} \mathrm{Ti}_{5} \mathrm{O}_{12}$ base on the redox couple of $\mathrm{Ti}^{3+} / \mathrm{Ti}^{4+}$ during the $\mathrm{Li}^{+}$intercalation/deintercalation processes ${ }^{16}$. So the effect of $\mathrm{Fe}_{3} \mathrm{O}_{4}$ doping is supposed to be the best, which could be verified in the subsequent electrochemical performance.

The SEM images of pure LTO, LTAO, LTNO and LFTO samples with the inserted histograms of particle size distribution are given in Fig. 2(a)-(d), respectively. After $\mathrm{Al}_{2} \mathrm{O}_{3}, \mathrm{NiO}$, $\mathrm{Fe}_{3} \mathrm{O}_{4}$ doping, the particle size of LTAO, LTNO and LFTO samples are smaller than that of pure LTO. The average particle size of pure LTO, LTAO, LTNO and LFTO samples are
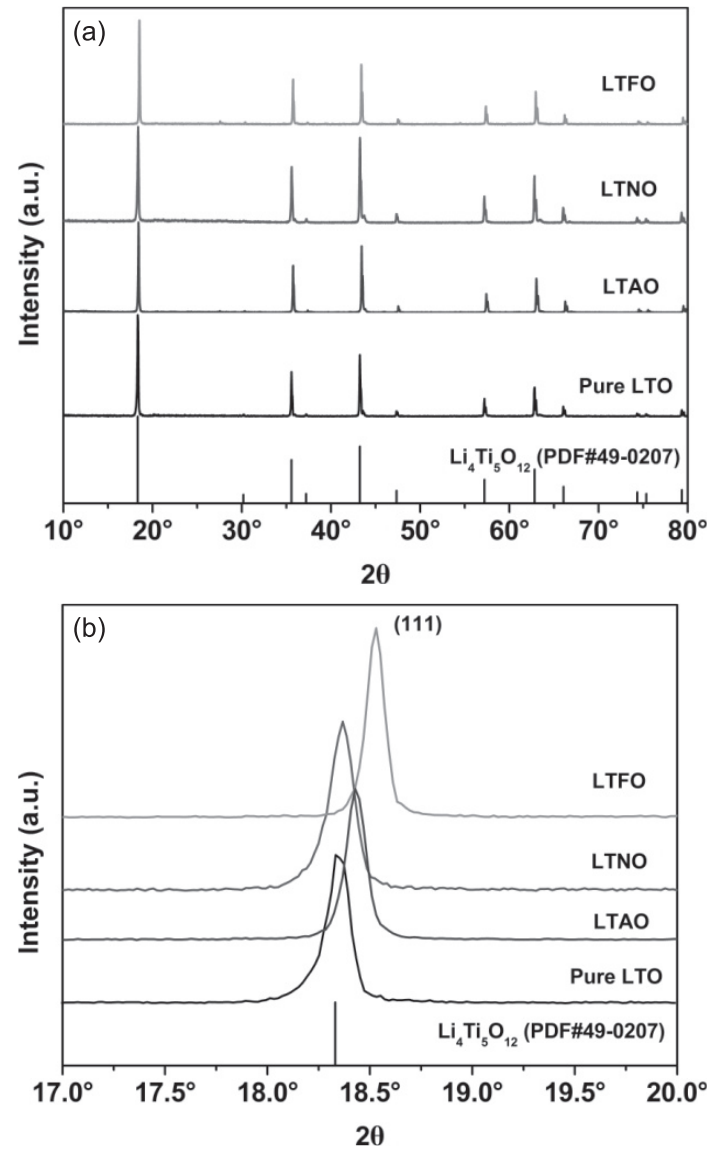

Fig. 1 XRD patterns of pure LTO, LTAO, LTNO, LTFO samples with PDF card of $\mathrm{Li}_{4} \mathrm{Ti}_{5} \mathrm{O}_{12}$ (No. 49-0207).

Table 1 Ionic radius of the relevant ions.

\begin{tabular}{lcccccccccc}
\hline Ions & $\mathrm{Li}^{+}$ & $\mathrm{Ti}^{4+}$ & $\mathrm{Al}^{3+}$ & $\mathrm{Ni}^{2+}$ & $\mathrm{Fe}^{2+}$ & $\mathrm{Fe}^{3+}$ & $\mathrm{La}^{3+}$ & $\mathrm{Ce}^{3+}$ & $\mathrm{O}^{2-}$ & $\mathrm{F}^{-}$ \\
\hline Ionic Radius $(\mathrm{nm})$ & 0.060 & 0.068 & 0.05 & 0.072 & 0.076 & 0.064 & 0.1061 & 0.1034 & 0.140 & 0.136 \\
\hline
\end{tabular}



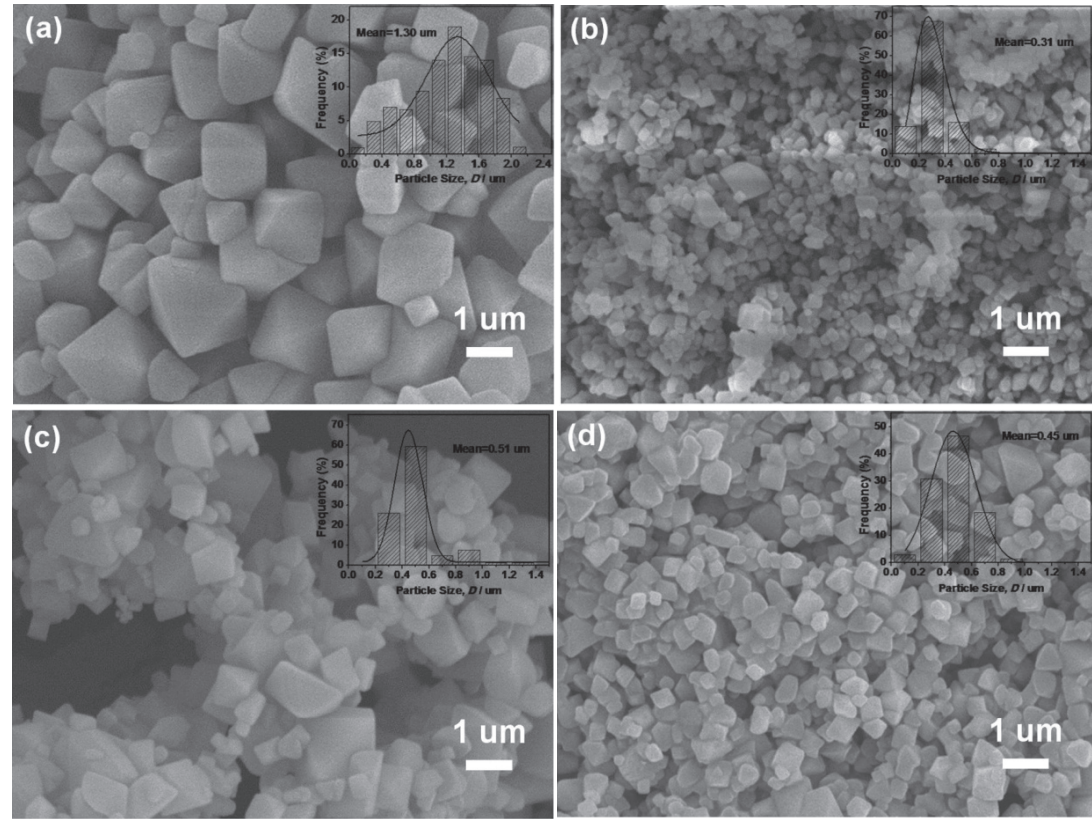

Fig. 2 SEM images of (a) pure LTO, (b) LTAO, (c) LTNO, (d) LTFO inserted with the histograms of particle size distribution calculated from the SEM images.

$1.3 \mu \mathrm{m}, 0.31 \mu \mathrm{m}, 0.51 \mu \mathrm{m}$ and $0.45 \mu \mathrm{m}$, respectively. The additive compound can participate in the synthesis reaction and enter into the crystal structure of LTO, resulting in smaller particle size of doped LTO, which coincided with the previous XRD results.

\subsection{Effect on structure and morphology by $\mathrm{La}_{2} \mathrm{O}_{3}, \mathrm{LaF}_{3}$ and $\mathrm{CeF}_{3}$ doping}

Figure 3(a) compares the XRD patterns of pure LTO, LT$\mathrm{La}_{0.1} \mathrm{O}, \mathrm{LTLa}_{0.2} \mathrm{O}$ samples. A impurity peak $\left(2 \theta=32.5^{\circ}\right)$ corresponding to $\mathrm{Li}_{0.485} \mathrm{La}_{0.505} \mathrm{TiO}_{3}$ phase was detected and it becomes stronger as the amount of added $\mathrm{La}_{2} \mathrm{O}_{3}$ increases. In Fig. 3(b), the peaks of the (111) plane have little shift after La doping, indicating than $\mathrm{La}^{3+}$ ions hardly substitute $\mathrm{Ti}^{4+}$ or $\mathrm{Li}^{+}$ ions in LTO, in agreement with the previous report ${ }^{33)}$. The possible reason is that the ionic radius of $\mathrm{La}^{3+}$ ion $(0.106 \mathrm{~nm})$ is much larger than that of $\mathrm{Ti}^{4+}$ ion or $\mathrm{Li}+$ ion. Figure $3(\mathrm{c})$ shows the XRD patterns of pure LTO, $\mathrm{LaF}_{3}$ modified LTO samples, no impurities were found in the samples of LTO or $\mathrm{LTLa}_{0.05} \mathrm{OF}_{0.15}$. Nevertheless, the impurity peaks in the XRD patterns of $\mathrm{LTLa}_{0.1} \mathrm{OF}_{0.3}, \mathrm{LTLa}_{0.15} \mathrm{OF}_{0.45}, \mathrm{LTLa}_{0.2} \mathrm{OF}_{0.6}$ samples were observed. The peak of the (111) plane in Fig. 3(d) shows the peak shift to lower diffraction angles, implying that the lattice parameter of LTO increases after $\mathrm{LaF}_{3}$ modification. The purity structure in $\mathrm{LTLa}_{0.05} \mathrm{OF}_{0.15}$ samples may be caused by the substitution of $\mathrm{O}^{2-}$ ions $(0.140 \mathrm{~nm})$ by the slightly smaller $\mathrm{F}^{-}$ions $(0.136 \mathrm{~nm})$ and a small amount of $\mathrm{La}^{3+}$ ions as charge compensation enter into the crystal lattice of $\mathrm{LTO}^{34)}$

Figure 4(a)-(h) display the SEM images of $\mathrm{LTLa}_{0.1} \mathrm{O}$, $\mathrm{LTLa}_{0.2} \mathrm{O}, \quad \mathrm{LTLa}_{0.05} \mathrm{OF}_{0.15}, \quad \mathrm{LTLa}_{0.1} \mathrm{OF}_{0.3}, \quad \mathrm{LTLa}_{0.15} \mathrm{OF}_{0.45}$, $\mathrm{LTLa}_{0.2} \mathrm{OF}_{0.6}, \mathrm{LTCe}_{0.05} \mathrm{OF}_{0.15}$ and $\mathrm{LTCe}_{0.1} \mathrm{OF}_{0.3}$ samples, respectively. In Fig. 4(a)-(b), $\mathrm{LTLa}_{0.1} \mathrm{O}$ and $\mathrm{LTLa}_{0.2} \mathrm{O}$ samples have exhibited similar morphology, octahedron particles with a size around $1.5 \mu \mathrm{m}$ and some nanorod impurities. However, SEM results of the $\mathrm{LTLa}_{0.05} \mathrm{OF}_{0.15}, \mathrm{LTLa}_{0.1} \mathrm{OF}_{0.3}$ samples in
Fig. 4(c)-(d) clearly displays pure, well-crystallized with particle sizes that are slightly smaller than that of pure LTO (in Fig. 2(a)). Furthermore, SEM images of $\mathrm{LTLa}_{0.15} \mathrm{OF}_{0.45}$ and $\mathrm{LTLa}_{0.2} \mathrm{OF}_{0.6}$ in Fig. 4(e)-(f), some nanorod impurities appear, which are similar to the morphology of $\operatorname{LTLa}_{0.1} \mathrm{O}$ and $\mathrm{LTLa}_{0.2} \mathrm{O}$ samples. The results indicate that some $\mathrm{La}^{3+}$ ions can enter into the crystal lattice of LTO after $\mathrm{F}^{-}$ion doping. However, with the amount of $\mathrm{LaF}_{3}$ increasing, the impurities, like $\mathrm{Li}_{0.485} \mathrm{La}_{0.505} \mathrm{TiO}_{3}$, generate. The SEM images of $\mathrm{LTCe}_{0.1} \mathrm{OF}_{0.3}$ and $\mathrm{LTCe}_{0.2} \mathrm{OF}_{0.6}$ samples in Fig. 4(g)-(h) show similar results compared with the $\mathrm{LTLa}_{0.05} \mathrm{OF}_{0.15}$ and LTLa ${ }_{0.1} \mathrm{OF}_{0.3}$ samples after $\mathrm{CeF}_{3}$ modifying. A small amount of $\mathrm{La}^{3+}$ or $\mathrm{Ce}^{3+}$, with a large ionic radius, can enter into the vacant space of the crystal lattice of LTO that is caused by $\mathrm{F}^{-}$ions substitution of $\mathrm{O}^{2-}$ ions in the structure of LTO. As a result, well-crystallized samples $\left(\mathrm{LTLa}_{0.05} \mathrm{OF}_{0.15}\right.$ and $\mathrm{LTLa}_{0.1} \mathrm{OF}_{0.3}$ ) with smaller particles and no impurities were obtained.

\subsection{Effect on rate performance after metallic oxide dop- ing}

The pure LTO, LTAO, LTNO, LTFO and $\operatorname{LTLa}_{\mathrm{x}} \mathrm{O}(\mathrm{x}=0.1$, 0.2 ) samples were used as coin battery anodes to examine the effects of different ionic radii on the electrochemical performances of LTO.

Figure 5(a) shows the rate performances of pure LTO, LTAO, LTNO and LTFO electrodes at different discharge/ charge rates in the 1.0-2.5 V voltage range. LTFO electrode exhibits the best discharge/charge capacity among the four electrodes, after the first discharge capacity of $269.3 \mathrm{mAh} \cdot \mathrm{g}^{-1}$, substantially stable at $240 \mathrm{mAh} \cdot \mathrm{g}^{-1}$ at $0.15 \mathrm{C}$, then the rate is gradually increased to $0.2 \mathrm{C}, 0.5 \mathrm{C}, 0.75 \mathrm{C}, 1 \mathrm{C}, 2 \mathrm{C}, 5 \mathrm{C}$ and $10 \mathrm{C}$ in sequence, the corresponding capacities of LTFO electrode are 230.4, 215.8, 207.3, 201.3, 186.3, 155.1 and $123.4 \mathrm{mAh} \cdot \mathrm{g}^{-1}$, respectively, while the pure LTO electrode delivers 134.2, 119.3, 108.5, 90.1, 82.9, 69.4 and 

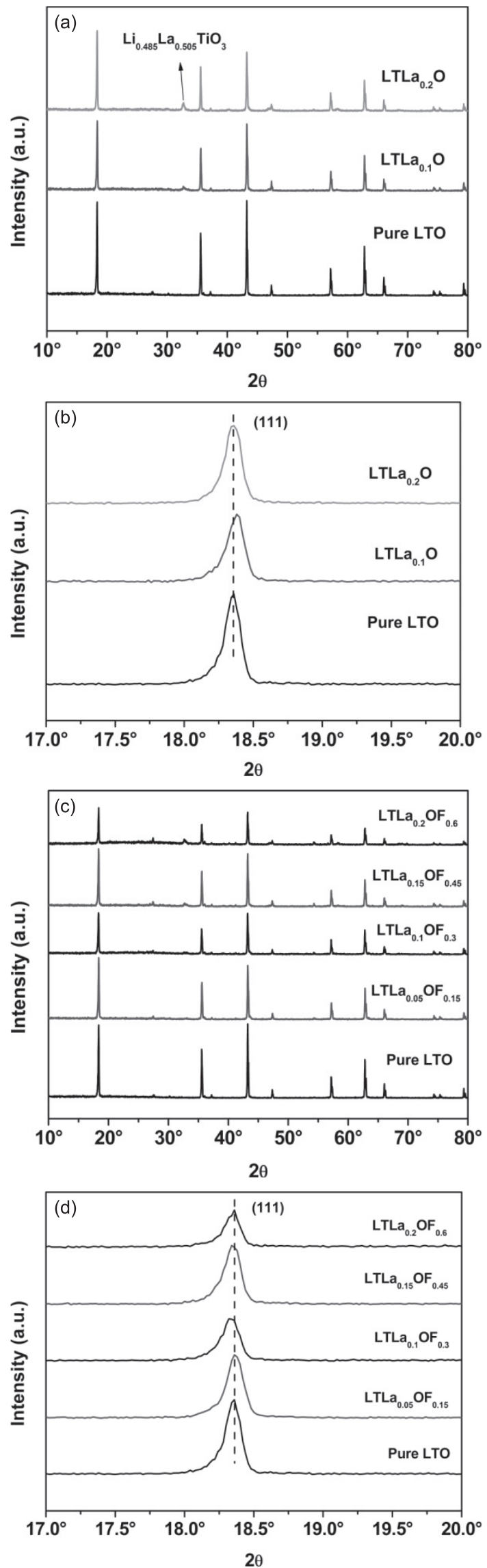

Fig. 3 (a) XRD patterns and (b) the (111) plane XRD peaks of pure LTO, LTLa $_{0.1} \mathrm{O}, \mathrm{LTLa}_{0.2} \mathrm{O}$ samples. (c) XRD patterns and (d) the (111) plane XRD peaks of pure LTO, $\mathrm{LTLa}_{0.05} \mathrm{OF}_{0.15}, \mathrm{LTLa}_{0.1} \mathrm{OF}_{0.3}, \mathrm{LTLa}_{0.15} \mathrm{OF}_{0.45}$, $\mathrm{LTLa}_{0.2} \mathrm{OF}_{0.6}$ samples.

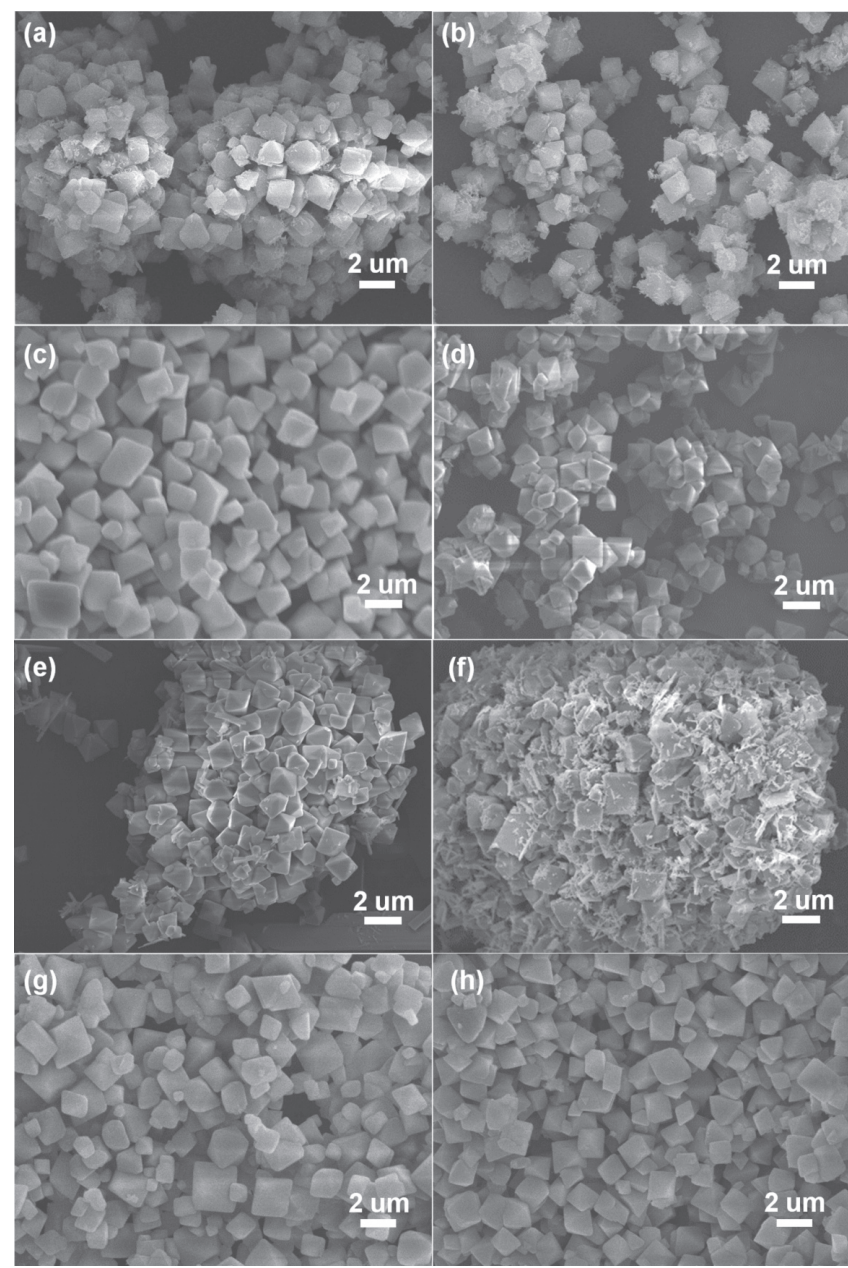

Fig. 4 SEM images of (a) $\operatorname{LTLa}_{0.1} \mathrm{O}$, (b) $\mathrm{LTLa}_{0.2} \mathrm{O}$, (c) $\mathrm{LTLa}_{0.05} \mathrm{OF}_{0.15}$, (d) $\mathrm{LTLa}_{0.1} \mathrm{OF}_{0.3}$, (e) $\mathrm{LTLa}_{0.15} \mathrm{OF}_{0.45}$, (f) $\mathrm{LTLa}_{0.2} \mathrm{OF}_{0.6}$, (g) $\mathrm{LTCe}_{0.05} \mathrm{OF}_{0.15}$ and (h) $\mathrm{LTCe}_{0.1} \mathrm{OF}_{0.3}$ samples, respectively.

$44.4 \mathrm{mAh} \cdot \mathrm{g}^{-1}$, respectively. LTAO electrode delivers a better discharge/charge capacity at high-rate than that of pure LTO electrode, substantially stable at $91 \mathrm{mAh} \cdot \mathrm{g}^{-1}$ at $10 \mathrm{C}$. However, LTNO electrode has a worse capacity than that of pure LTO. At $10 \mathrm{C}$ rate, the capacity of LTNO electrode just receives $33 \mathrm{mAh} \cdot \mathrm{g}^{-1}$. Figure 5(b) displays the first cycle discharge/charge curves of LTAO and LTFO electrodes at different $\mathrm{C}$ rates. All the curves show a flat voltage plateau around $1.55 \mathrm{~V}\left(\mathrm{vs} . \mathrm{Li} / \mathrm{Li}^{+}\right)$, corresponding to the reduction/oxidation reaction between $\mathrm{Li}_{4} \mathrm{Ti}_{5} \mathrm{O}_{12}$ and $\mathrm{Li}_{7} \mathrm{Ti}_{5} \mathrm{O}_{12}$ during the $\mathrm{Li}^{+}$intercalation/deintercalation process ${ }^{35,36)}$.

The rate performances of $\mathrm{LTLa}_{0.1} \mathrm{O}$ and $\mathrm{LTLa}_{0.2} \mathrm{O}$ electrodes are also shown in Fig. 5(c). The $\mathrm{LTLa}_{0.2} \mathrm{O}$ electrode gives better capacities $(160.7,116.4,98.3,75.5$ and $55 \mathrm{mAh} \cdot \mathrm{g}^{-1}$ at $0.2 \mathrm{C}, 0.5 \mathrm{C}, 0.75 \mathrm{C}, 1 \mathrm{C}, 2 \mathrm{C}$ and $5 \mathrm{C}$, respectively) than that of $\mathrm{LTLa}_{0.1} \mathrm{O}$ electrode. However, the rate performance of $\mathrm{LTLa}_{0.2} \mathrm{O}$ electrode is worse than that of pure LTO. Figure 5(d) compares the specific discharge capacity at different rates for pure LTO and all the doped samples synthesized by molten salt method in our lab. The capacity for the samples decreases with increasing rate, while the capacity drops slowly when the rate is higher than $1 \mathrm{C}$. Obviously, the capacity and rate capability improves as the $\mathrm{Al}_{2} \mathrm{O}_{3}, \mathrm{Fe}_{3} \mathrm{O}_{4}$, $\mathrm{Fe}_{2} \mathrm{O}_{3}$ and $\mathrm{Co}_{3} \mathrm{O}_{4}$ doped into LTO. In particular, the $\mathrm{Fe}_{3} \mathrm{O}_{4}$ 

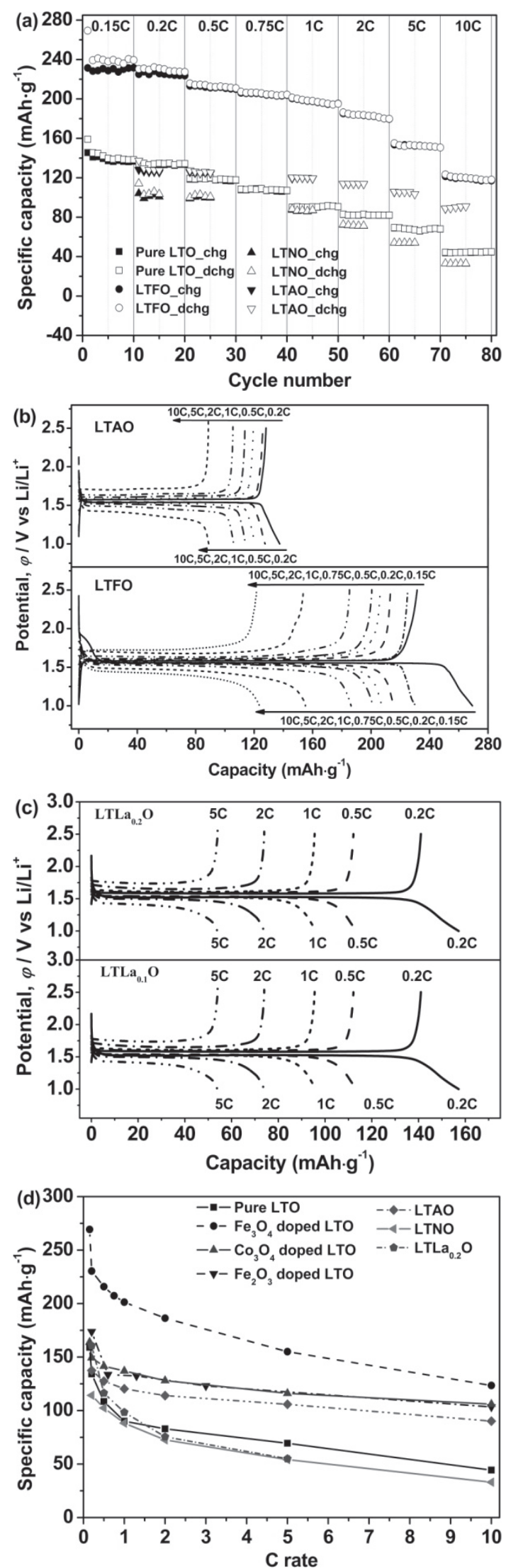

Fig. 5 (a) The rate performances of pure LTO, LTAO, LTNO and LTFO electrodes at different $\mathrm{C}$ rates. The first discharge/charge curves of (b) LTAO and LTFO, (c) $\mathrm{LTLa}_{0.1} \mathrm{O}$ and $\mathrm{LTLa}_{0.2} \mathrm{O}$ electrodes at different $\mathrm{C}$ rates. (d) Dependence of specific capacity for the metallic oxide doped LTO samples by molten salt method on current density. doped LTO (LTFO) shows the best capacity and rate performance.

\subsection{Effect on cycle performance after metallic oxide dop- ing}

Figure 6(a)-(d) display the discharge/charge cycle performance and coulombic efficiency of pure LTO, LTAO, LTNO and LTFO, respectively. In Fig. 6(a), the pure LTO electrode, with obvious fluctuation, delivers the first discharge capacity of $179.3 \mathrm{mAh} \cdot \mathrm{g}^{-1}$ at $0.2 \mathrm{C}$ rate, after 5 cycles, it decreases to $96 \mathrm{mAh} \cdot \mathrm{g}^{-1}$, and then $106.5 \mathrm{mAh} \cdot \mathrm{g}^{-1}$ after the following 205 cycles at $1 \mathrm{C}$ rate. Fig. 6(b) shows that the LTAO electrode exhibits a first discharge capacity of $150.9 \mathrm{mAh} \cdot \mathrm{g}^{-1}(93.6 \%$ coulombic efficiency of the first cycle), then capacity fades to $136.8 \mathrm{mAh} \cdot \mathrm{g}^{-1}$ after 100 cycles at $0.2 \mathrm{C}$ rate. However, the LTNO electrode in Fig. 6(c), with the slight fluctuation, delivers the first discharge capacity of $116.9 \mathrm{mAh} \cdot \mathrm{g}^{-1}$ at $0.2 \mathrm{C}$ rate, then $110.8 \mathrm{mAh} \cdot \mathrm{g}^{-1}$ after 100 cycles at $0.2 \mathrm{C}$ rate. From Fig. 6(d), the LTFO electrode exhibits a first discharge capacity of $161.1 \mathrm{mAh} \cdot \mathrm{g}^{-1}$ at $1 \mathrm{C}$ rate, stable at $147 \mathrm{mAh} \cdot \mathrm{g}^{-1}$ for 100 cycles, then fading to $141.1 \mathrm{mAh} \cdot \mathrm{g}^{-1}$ at the $300^{\text {th }}$ cycle, which gives $12.4 \%$ loss of capacity. From Fig. 6(a)-(d), the coulombic efficiency of the first cycle of pure LTO is $80.4 \%$, which are $93.6 \%$ for LTAO, $90.4 \%$ for LTNO and $90.1 \%$ for LTFO, respectively. Then the four electrodes receive high recharge coulombic efficiency close to $100 \%$. The $1^{\text {st }}, 50^{\text {th }}$ $100^{\text {th }}, 200^{\text {th }}, 300^{\text {th }}$ discharge/charge curves of LTFO electrode in Fig. 6(e) clearly illustrate that the LTFO electrode has good cycling stability after 300 discharge/charge cycles and the reduction/oxidation reaction of LTFO electrode occurs at about $1.55 \mathrm{~V}$, corresponding to the two-phase transition between $\mathrm{Li}_{4} \mathrm{Ti}_{5} \mathrm{O}_{12}$ and $\mathrm{Li}_{7} \mathrm{Ti}_{5} \mathrm{O}_{12}$. Figure 6(f) exhibits the similar cycle performance of the $\mathrm{LTLa}_{0.1} \mathrm{O}$ and $\mathrm{LTLa}_{0.2} \mathrm{O}$ electrodes at $0.2 \mathrm{C}$ rate for 50 cycles. The first discharge capacity of the $\mathrm{LTLa}_{0.1} \mathrm{O}$ electrode is $166 \mathrm{mAh} \cdot \mathrm{g}^{-1}$, than stable at $135 \mathrm{mAh} \cdot \mathrm{g}^{-1}$ in the following 49 cycles.

In conclusion, the LTFO electrode shows the best electrochemical performance in all the electrodes. This may be caused by the smaller particle size, uniform particle distribution, the similar ionic radii with $\mathrm{Li}^{+}$and $\mathrm{Ti}^{4+}$, and the co-doping of variable valence $\mathrm{Fe}^{2+}$ and $\mathrm{Fe}^{3+}$ ions largely affect the redox reaction as the two-phase reaction of $\mathrm{Li}_{7} \mathrm{Ti}_{5} \mathrm{O}_{12} /$ $\mathrm{Li}_{4} \mathrm{Ti}_{5} \mathrm{O}_{12}$ based on the redox couple of $\mathrm{Ti}^{3+} / \mathrm{Ti}^{4+}$ during $\mathrm{Li}^{+}$ intercalation/deintercalation process ${ }^{16,37)}$.

\section{Conclusions}

In this paper, different metallic compounds $\left(\mathrm{Al}_{2} \mathrm{O}_{3}, \mathrm{NiO}\right.$, $\mathrm{Fe}_{3} \mathrm{O}_{4}, \mathrm{La}_{2} \mathrm{O}_{3}, \mathrm{LaF}_{3}, \mathrm{CeF}_{3}$ ) with different ionic radii doped into LTO were synthesized via the molten salt method. $\mathrm{Al}_{2} \mathrm{O}_{3}$, $\mathrm{Fe}_{3} \mathrm{O}_{4}, \mathrm{NiO}$ or $\mathrm{LaF}_{3}$ doping can generate smaller particle size of LTO. However, the addition of $\mathrm{La}_{2} \mathrm{O}_{3}$ cannot decrease the particle size of LTO. Thereafter, the addition of $\mathrm{LaF}_{3}$ or $\mathrm{CeF}_{3}$ can lead to slightly smaller particle sizes. Hence, doped cations $\left(\mathrm{Al}^{3+}, \mathrm{Ni}^{2+}, \mathrm{Fe}^{2+}, \mathrm{Fe}^{3+}\right)$ or anion $\left(\mathrm{F}^{-}\right)$with similar ionic radius as $\mathrm{Li}^{+}, \mathrm{Ti}^{4+}$ or $\mathrm{O}^{2-}$ ions can enter into $\mathrm{LTO}$. $\mathrm{La}^{3+}$ with a much larger ionic radius cannot enter into LTO.

With the most closest ionic radius to that of the $\mathrm{Li}^{+}, \mathrm{Ti}^{4+}$ ions, the co-doping of $\mathrm{Fe}^{2+}$ and $\mathrm{Fe}^{3+}$ ions in LTO exhibits the best rates and cycle performance among all the doped sam- 

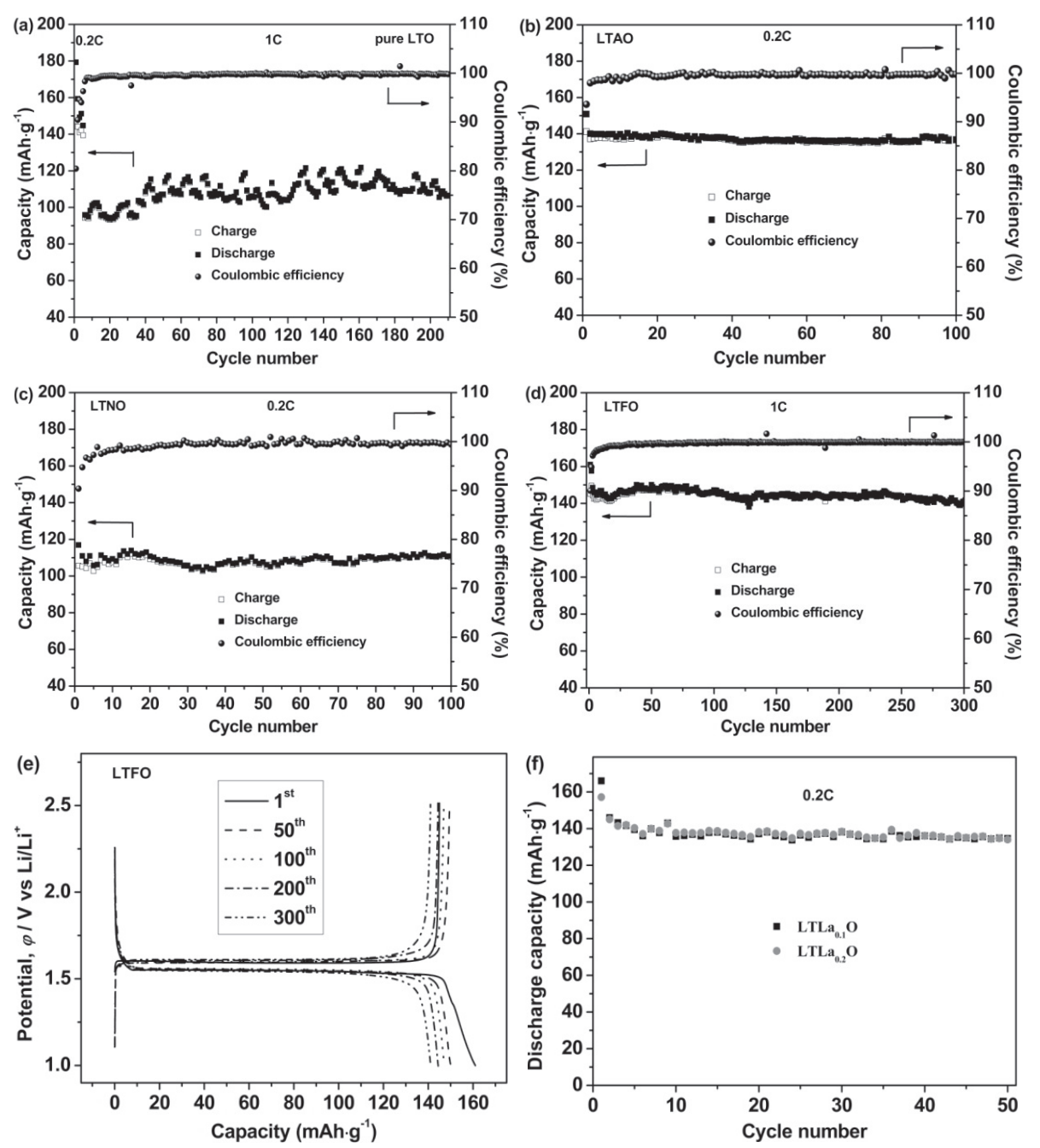

Fig. 6 The cyclability and coulombic efficiency of (a) pure LTO, (b) LTAO, (c) LTNO and (d) LTFO electrodes. (e) The first, $50^{\text {th }}, 100^{\text {th }}, 200^{\text {th }}$, and $300^{\text {th }}$ discharge/charge curves in the $1-2.5 \mathrm{~V}$ voltage of LTFO electrode at $1 \mathrm{C}$ rate. (f) The discharge cyclability of LTLa ${ }_{0.1} \mathrm{O}$ and LTLa ${ }_{0.2} \mathrm{O}$ electrode under $0.2 \mathrm{C}$ rate for 50 cycles.

ples: an excellent first discharge capacity of $269.3 \mathrm{mAh} \cdot \mathrm{g}^{-1}$ at the $0.15 \mathrm{C}, 201.3 \mathrm{mAh} \cdot \mathrm{g}^{-1}$ at $1 \mathrm{C}$, good high-rate capability $\left(123.4 \mathrm{mAh} \cdot \mathrm{g}^{-1}\right.$ at $\left.10 \mathrm{C}\right)$; even after 300 discharge/charge cycles at $1 \mathrm{C}$ rate, the discharge capacity is $141.1 \mathrm{mAh} \cdot \mathrm{g}^{-1}$, gives an excellent cycle performance with $12.4 \%$ loss of capacity. These result indicate that ions doping can improve the intrinsic conductivity of LTO and also can reduce the particle size of LTO, leading to the improved specific surface area and shortened $\mathrm{Li}^{+}$transfer path, which could efficiently enhance the electrochemical performance of LTO. As such, the molten salt method with ion doping promises to be the next generation industrial production method of LTO.

\section{Acknowledgments}

This work was supported by the National Natural Science Foundation of China (no. 51474107).

\section{REFERENCES}

1) J. Guo, W. Zuo, Y. Cai, S. Chen, S. Zhang and J. Liu: J. Mater. Chem. A 3 (2015) 4938-4944.

2) L. Wen, Z. Wu, H. Luo, R. Song and F. Li: J. Electrochem. Soc. 162
(2015) A3038-A3044.

3) L. Wang, Y. Zhang, M.E. Scofield, S. Yue, C. McBean, A.C. Marschilok, K.J. Takeuchi, E.S. Takeuchi and S.S. Wong: ChemSusChem 8 (2015) 3304-3313.

4) W. Li, X. Li, M. Chen, Z. Xie, J. Zhang, S. Dong and M. Qu: Electrochim. Acta 139 (2014) 104-110.

5) L. Zhao, Y.S. Hu, H. Li, Z. Wang and L. Chen: Adv. Mater. 23 (2011) 1385-1388.

6) Y.B. He, B. Li, M. Liu, C. Zhang, W. Lv, C. Yang, J. Li, H. Du, B Zhang, Q.H. Yang, J.K. Kim and F. Kang: Sci. Rep. 2 (2012) 913.

7) K. Wu, J. Yang, Y. Liu, Y. Zhang, C. Wang, J. Xu, F. Ning and D. Wang: J. Power Sources 237 (2013) 285-290.

8) B. Zhao, R. Ran, M.L. Liu and Z.P. Shao: Mater. Sci. Eng. Rep. 98 (2015) $1-71$.

9) L. Wang, X. He, J. Li, W. Sun, J. Gao, J. Guo and C. Jiang: Angew. Chem. Int. Ed. Engl. 51 (2012) 9034-9037.

10) M. Lao, X. Lin, P. Li, L. Shao, K. Wu, M. Shui, N. Long, Y. Ren and J. Shu: Ceram. Int. 41 (2015) 2900-2907.

11) Q. Guo, S. Li, H. Wang, Y. Gao and B. Li: RSC Adv. 4 (2014) 6032760333.

12) Q. Guo, Q. Wang, G. Chen, H. Xu, J. Wu and B. Li: ECS Trans. 72 (2016) 11-23.

13) V.D. Nithya, R. Kalai Selvan, K. Vediappan, S. Sharmila and C.W. Lee: Appl. Surf. Sci. 261 (2012) 515-519.

14) T.-F. Yi, S.-Y. Yang, X.-Y. Li, J.-H. Yao, Y.-R. Zhu and R.-S. Zhu: J. Power Sources 246 (2014) 505-511.

15) D. Wang, C. Zhang, Y. Zhang, J. Wang and D. He: Ceram. Int. 39 (2013) 5145-5149. 
16) M. Ji, Y. Xu, Z. Zhao, H. Zhang, D. Liu, C. Zhao, X. Qian and C. Zhao: J. Power Sources 263 (2014) 296-303.

17) Z. Wang, Z. Wang, W. Peng, H. Guo and X. Li: Ceram. Int. 40 (2014) 10053-10059.

18) Y.Q. Wang, L. Gu, Y.G. Guo, H. Li, X.Q. He, S. Tsukimoto, Y. Ikuhara and L.J. Wan: J. Am. Chem. Soc. 134 (2012) 7874-7879.

19) S. Zheng, Y. Xu, C. Zhao, H. Liu, X. Qian and J. Wang: Mater. Lett. 68 (2012) 32-35.

20) J. Liu, W. Liu, S. Ji, Y. Wan, H. Yin and Y. Zhou: Eur. J. Inorg. Chem. 2014 (2014) 2073-2079.

21) M. Hu, Y. Jiang and M. Yan: J. Alloy. Compd. 603 (2014) 202-206.

22) J. Wang, Z. Yang, W. Li, X. Zhong, L. Gu and Y. Yu: J. Power Sources 266 (2014) 323-331.

23) M. Krajewski, M. Michalska, B. Hamankiewicz, D. Ziolkowska, K.P. Korona, J.B. Jasinski, M. Kaminska, L. Lipinska and A. Czerwinski: J. Power Sources 245 (2014) 764-771.

24) Q. Zhang, Y. Liu, H. Lu, D. Tang, C. Ouyang and L. Zhang: Electrochim. Acta 189 (2016) 147-157.

25) W. Li, H. Wang, M. Chen, J. Gao, X. Li, W. Ge, M. Qu, A. Wei, L. Zhang and Z. Liu: Electrochim. Acta 188 (2016) 499-511

26) Z. Ding, L. Zhao, L. Suo, Y. Jiao, S. Meng, Y.S. Hu, Z. Wang and L. Chen: Phys. Chem. Chem. Phys. 13 (2011) 15127-33.

27) J. Chen, L. Yang, S. Fang and Y. Tang: Electrochim. Acta 55 (2010)
6596-6600.

28) T. Kimijima, K. Kanie, Y. Tsujikawa, M. Nakaya, N. Zettsu, K. Teshima and A. Muramatsu: Ceram. Int. 41 (2015) 10988-10994.

29) X. Li, H. Hu, S. Huang, G. Yu, L. Gao, H. Liu and Y. Yu: Electrochim. Acta 112 (2013) 356-363.

30) W. Yao, W. Zhuang, X. Ji, J. Chen, X. Lu and C. Wang: Mater. Res. Bull. 75 (2016) 204-210.

31) T. Ogihara, M. Yamada, A. Fujita, S. Akao and K. Myoujin: Mater. Res. Bull. 46 (2011) 796-800.

32) T.-F. Yi, S.-Y. Yang, M. Tao, Y. Xie, Y.-R. Zhu and R.-S. Zhu: Electrochim. Acta 134 (2014) 377-383.

33) T.-F. Yi, Y. Xie, Q. Wu, H. Liu, L. Jiang, M. Ye and R. Zhu: J. Power Sources 214 (2012) 220-226.

34) S. Huang, Z. Wen, Z. Gu and X. Zhu: Electrochim. Acta 50 (2005) 4057-4062.

35) J. Haetge, P. Hartmann, K. Brezesinski, J. Janek and T. Brezesinski: Chem. Mater. 23 (2011) 4384-4393.

36) M.R. Jo, G.H. Lee and Y.M. Kang: ACS Appl. Mater. Interfaces 7 (2015) 27934-27939.

37) M.R. Jo, J. Jung, G.-H. Lee, Y. Kim, K. Song, J. Yang, J.S. Chae, K.C. Roh, Y.-I. Kim, W.-S. Yoon and Y.-M. Kang: Nano Energy 19 (2016) 246-256. 